\title{
Green Roof: An approach to repair the climate of Dhaka city
}

\author{
Ferdous Farhana HUQ, Rajshahi University of Engineering \& Technology; Bangladesh \\ Nidalia ISLAM, Bangladesh University of Engineering \& Technology; Bangladesh \\ Sakib ZUBAYER, Rajshahi University of Engineering \& Technology; Bangladesh \\ Nessar Uddin Ahmed, Development Design Consultants Limited, Bangladesh
}

\begin{abstract}
Dhaka the capital of Bangladesh looks no better than a piece of hardscape from aerial view which justifies the swelling concern of replacing green areas with built up areas to fulfill the demand of briskly growing urban population. Increasing air temperature, changing rainfall pattern and 'unhealthy' air bears the proof of Dhaka city being an urban heat island created by the present development trend. Unrecoverable damage has already been done to the green spaces of this city which has turned this city as the most polluted city in the world. At the edge of the collapse of sustainability of this city new approaches such as 'green roof' can be used to repair its lungs. Although rooftop gardening has been a traditional concept in Bangladesh, in city-wide scale a very few buildings can be seen with green space in roof or balconies. This study employs satellite image analysis and GIS technology to identify the buildings with a green roof. This study uses a questionnaire survey to explore the commonly used green roof method, motivation benefits and challenges behind the implementation of the green roof. This research presents the global scenario of green roof and explores the possibilities of developing the green roof approach in city scale in Dhaka city.
\end{abstract}

\section{Keywords}

Green roof, Rooftop gardening, Urban Heat Island, Climate change, Satellite image analysis

\section{Introduction}

The world is going through a trend of migration, Poor infrastructure design, social and economic challenges are pushing people towards cities. Study shows that by 2050 the level of world's urbanization will be up to $69 \%$ whereas $86 \%$ people of the developed nation and $66 \%$ people from less developed nations will be urban dwellers (Hui, 2011). Dhaka, the capital of Bangladesh is the home of 18 million people and has ranked as the densest city in the world with 47,400 people per square mile (Amin, 2019). Such rapid urbanization imposes excessive development pressure as any land is lucrative for physical development and construction due to heavy demand for it. As a result, Dhaka has lost its wetland areas significantly and this city occupies only $1 \%$ of its total land for parks and open spaces whereas in many modern metropolises this percentage is almost 20\%-30\% (RAJUK, 2015). Maheng et al (2019) mention Dhaka suffering from Urban Heat Island Effect (UHIE) along with other megacities of the world. UHIE is mainly generated when urban green space is replaced by thermal materials that store solar energy which lead to the increase of surrounding air temperature once it is re-emitted (Maheng et.al, 2019), Parvin and Adubu 
(2017) addressed the UHI of Dhaka city from 2002 to 2014 by using remote sensing technique. Their study presents from 2002 to 2014 the built-up area of the city increased from 74.12 to 135.36 square kilometers. By these 12 years, the average yearly temperature has increased by 5 degree Celsius and this study suggested to focus on urban greening to curb the heating effect (Parvin and Adubu (2017). At present context, green roof, rooftop gardening, rooftop farming has become a new trend in many countries to utilize the built-up areas for greening as well as a source of urban food production (Safayet et al, 2017, green roof policies incentives and guidelines, 2014, Rahman et al, 2014, Patnaik et al, 2014, Sam and Hui, 2014, Rowe, 2010, Vazhacharickal, 2014, Shuvo and Hakim, 2013). This idea has not been adequately practiced in Dhaka city whereas that most of the roofs of Dhaka city are suitable for gardening and do not require major improvement work rather need some modifications (Islam, 2004 in Safayet et al 2017). Based on the discussed context this study aims at identifying the rooftop gardens of the research area, hardscape- softscape ratio of the research area, overall scenario of rooftop gardening practice, challenges and how this practice can be promoted widely from planning perspectives.

\section{Gardening, Rooftop gardening, and Green roof}

The root of the gardening lies in the ancient culture where a garden was seen not only as a source of food but also a sign of prestige and affluence especially which were extensively ornamental and associated with villas and palace of wealthy (Carroll, 2003). Gardening originated in Egypt continuing and evolving through the civilization of Mesopotamia, Greek, Roman, Medieval to reach the contemporary age and has given birth to the idea of formal landscaping (Lambert, 2019, Managbanang, 2013 Carroll, 2003). The origin of Green roof or rooftop gardening lies in the terrace garden from an ancient culture. The earliest known record of terrace garden is the ancient Ziggurat from Ur city of Mesopotamia. Hanging garden of Babylon by King Nebuchadnezzar is another example of a terrace garden which is considered as one of the seven wonders from the ancient world (Cartwright, 2018; Shamim, 2013). The formal definition of a rooftop garden says that it is a technique of growing plants on the roof of a building by using containers (Chicago dept. of Environment n.d; Spacey, 2016). Whereas Green roof is a technique of growing plants on the rooftop of a building over a protective waterproof membrane that separate hard roof from the soil (Rowe, 2011, Spacey, 2016). Generally, two types of a green roof are constructed which are extensive and intensive.

\begin{tabular}{|l|l|}
\hline Extensive & Intensive \\
\hline Height: $6-15 \mathrm{~cm}$ & Height: $15 \mathrm{~cm}->1 \mathrm{~m}$ \\
weight: $60-150 \mathrm{~kg} / \mathrm{sqm}$ & weight: $180-500 \mathrm{~kg} / \mathrm{sqm}$ \\
vegetation: Moss, herb, grass & vegetation: Shrubs, perennials, small trees \\
Retains water: $70-130 \mathrm{l} / \mathrm{sqm}$ & Retains water: $22-451 \mathrm{l} / \mathrm{sqm}$ \\
Minimal irrigation, nutrient, and & $\begin{array}{l}\text { More irrigation, fertigation, and } \\
\text { maintenance }\end{array}$ \\
\hline
\end{tabular}

Source: Hossain et al 2019; Jafari et.al, 2015

Although Rooftop gardening is the umbrella concept of the green roof there is a major benefit of a green roof over RTG which is, a green roof can retain stormwater where RTG does not provide this facility. 


\section{Green roof adaptation example and prospects in Bangladesh}

The evidence from the study on the 'Secret garden located at the rooftop of a shopping complex in Malaysia suggest that having greenery element such as a green roof helps in regenerating and revitalizing the commercial setting in urban area and it helped people to be aware of green roof and its benefits (Rahman et.al, 2015). Singapore set an example of establishing a hydroponics green roof in 1988 in Changi general hospital (Jafari et al,2018; Mastura et. al 2017). Laski in Bangkok is a good example of rooftop gardening where this project intended to grow healthy vegetables for household consumption of the city and enhancing the green of the city (Hui, 2011; Jafari et al 2018). Hui (2011) in his study summarized different cases on green roof and RTG from all over the world. He discussed one case about 'Santropol Roulant' an NGO run by young people that supports RTG to ensure good health and food security of the senior citizen. RTG is now being commercially practiced in few areas of USA. The UK has undertaken low carbon policy and to implement this policy they are using RTG as a tool and now $14 \%$ of residents of London grow some foods in their gardens. Tokyo has passed an ordinance where it has been made mandatory for the buildings to keep green in $20 \%$ of its rooftops. Roppongi Hills at the center of Tokyo has RTG where paddy and vegetables are grown. Another great example of encouraging RTG is the law amendment by Taiwan government in 1995 declaring the rooftop as the public space so that tenants of the buildings can access the roof to use fully for storing things, plantations and drying clothes. These initiatives have enhanced RTG in the cities of Taiwan (Hui, 2014). Vazhacharickal (2014) in his study presented some exemplary cases of terrace garden as well as balcony gardens from Mumbai. In this study, he figured out major actors such as Marathi Vidnyan Parishad, Urban leaves, Mumbai port trust and Vidya Vaaridhi Trust who give advice, training, and awareness to people to set urban farms, terrace gardens and kitchen gardens (Vazhacharickal, 2014). Poddat et al (2017) scientifically proved the effectiveness of green vegetation on reducing heat gain and heat loss through the walls during summer and winter respectively.

Several types of research have been conducted on green roof practice in Bangladesh. Roy et.al (2016) presented homestead and rooftop gardening as one of the major techniques of enhancing urban forestry and urban greening for sustainable development in Dhaka city. Department of Agriculture Extension (DAE), Bangladesh launched "Integrated Quality Horticulture development projects enlisted 68 people from different parts of Dhaka city whom they train them to conduct rooftop gardening (Mastura et al, 2017). Many studies have mentioned about lack of initiatives from the government as the major reason for not practicing RTG. Therefore, such types of initiative from the government, as well as NGOs, are needed in higher numbers to repair the climate of the city. Shuvo and Hakim (2014) designed a compensative greening framework targeting rooftop gardening and apartment surface landscaping for reviving the green of Dhaka city.

\section{Method of the Study}

\subsection{Study area}

Ward 20 from the Zone 3 of Dhaka north city corporation is selected as the research area (Dhaka North City Corporation, 2016; Mediabangladesh.Net, N.D). The official ward name of this area is Mohakhali Niketon. This area is comprised of Mohakhali Shantiniketon residential 
area and Gulshan Niketon housing area and located at the heart of Dhaka north city corporation. In this area primarily four types of land uses are observed which are residential, commercial, mixed-use and administrative. Among the land uses, the residential area comprises $72 \%$ and other land uses occupy $28 \%$. Mohakhali slum occupies $25.8 \%$, Gulshan Niketon area Occupies $26 \%$ and Mohakhali Shantiniketon residential cover $48.2 \%$ of the total residential area of the selected study area (RAJUK, 2004).

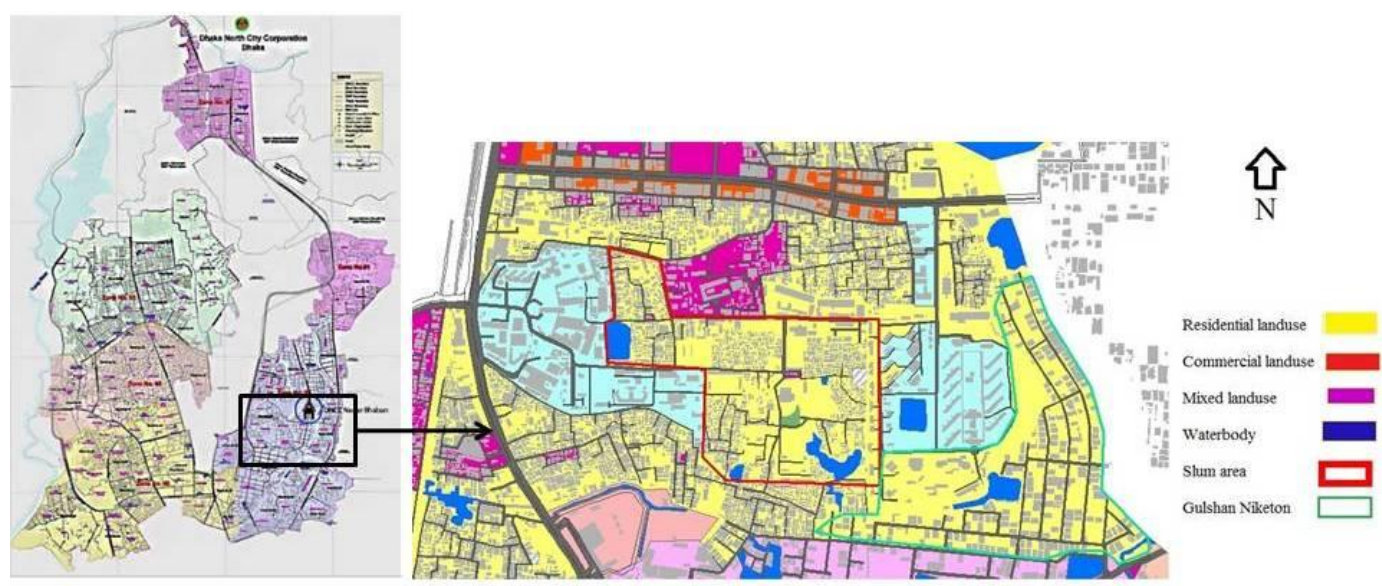

Figure 1 Research Area

Source: Prepared by Author by using Dhaka North City Corporation, 2016 and RAJUK 2004 data

\subsection{Satellite Image analysis}

WorldView-3 Satellite Mono 4 band (Red, Green, Blue, NIR) Image has been used in this study. The image was taken on $04^{\text {th }}$ August 2018. The resolution of the image was $40 \mathrm{~cm}$ and it was clear enough to avoid any noise and cloud reduction operation. The satellite image was projected using Universal Transverse Mercator (UTM) within Zone $46 \mathrm{~N}$ - Datum World Geodetic System (WGS) 84. Training samples were developed in Geographic Information System (GIS) to create a signature file for supervised classification. Training sites are manually taken polygons from each type of land cover that identify and represent that particular type of and cover and the statistical characterization of these land cover using training sites is called the signature file (Good child, 2009). Maximum Likelihood Supervised Classification, using training sample and signature file, has been performed in order to classify the land cover and identify the rooftop vegetation as well. The land cover was divided into 4 classes such as Built up area including buildings and roads, rooftop vegetation, regular vegetation, and water body. Accuracy of the performed classification was assessed using Kappa Coefficient. In this regard, 280 ground truth points (70 from each class) have been taken from Google earth image of the study area of August 2018. Converting to raster pixels in the same resolution of the image, these random reference points have been compared to the classified image to calculate total accuracy and Kappa Coefficient. The value of the Kappa Coefficient varies from 0 to 1.00 , while value over 0.7 is considered as acceptable (Daniel and Montero, 2011). The calculated value of the Kappa Coefficient was 0.87 which means the accuracy was acceptable.

\subsection{Field Survey}

Rooftop garden owner or the caretaker from 30 selected buildings from the research area was surveyed with a structured questionnaire. Survey findings were analyzed by using statistical tools. 


\section{Results and Discussions}

\subsection{Vegetation Condition of the research area}

Satellite image analysis figured out that the rooftop vegetation covers almost $10 \%$ of the research area which proves the ongoing practices of rooftop gardening in ward 20 as well as justifies RTG's prospects to be practiced in city scale. Except rooftop gardening, other vegetations cover $26 \%$ of the study area whereas the built-up area covers $64 \%$ of the research area. At the current scenario hardscape vs softscape ratio is 1.8:1. If the percentage of RTG is omitted hardscape vs softscape ratio becomes $2.8: 1$. Therefore it is evident that RTG can significantly overshadow the hardscape ratio and contribute to enhancing the total softscape amount of the city.

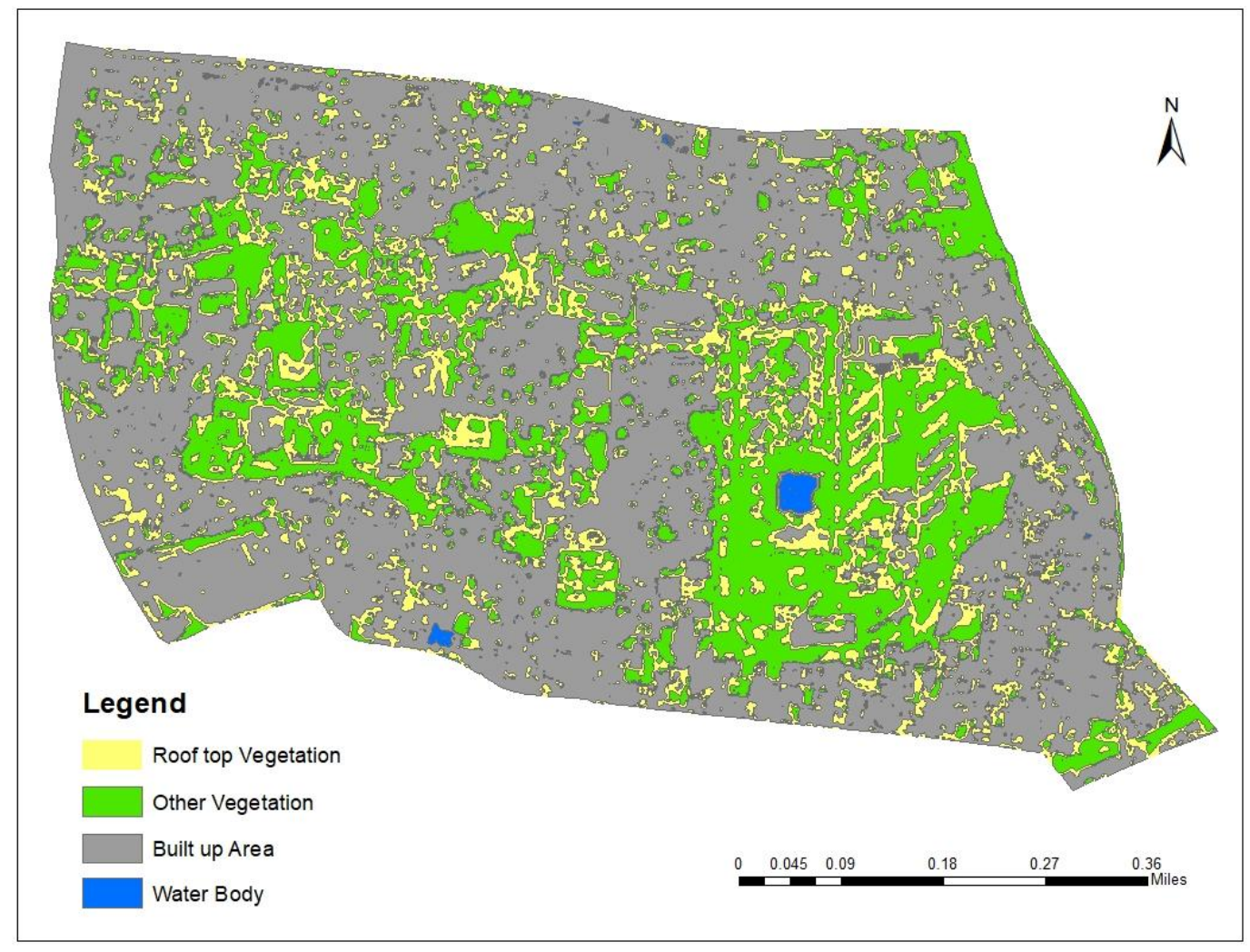

Figure 2 Vegetation and built up area in Ward 20

Source Author's preparations and adaptations from WorldView-3, Maxar Technologies Inc., (Formerly DigitalGlobe)

Table 1 Vegetation and Built up area Percentage in Ward 20

\begin{tabular}{|l|r|r|}
\hline Land Cover Type & Area (Sq meter) & Percentage \\
\hline Built up area & 762939 & 64 \\
\hline Rooftop Vegetation & 123540 & 10 \\
\hline Other Vegetation & 309501 & 26 \\
\hline Waterbody & 4408 & 0 \\
\hline Total & $\mathbf{1 2 0 0 3 8 8}$ & $\mathbf{1 0 0}$ \\
\hline
\end{tabular}

Source Prepared by Author 


\subsection{Motivation and Purpose of RTG}

People living in Mohakhali Shantiniketon residential area and Gulshan Niketan housing share the same interest and enthusiasm towards roof gardening although the two areas have different aspects from a spatial point of view and urban facilities. Along with hobby working as the primary motivation for roof gardening, family members inspiration is also another important drive as in many case studies more than one family members are involved in gardening and they also inspire each other. The percentage of paid personnel is greater in Gulshan Niketan whereas the involvement of owner and caretaker are almost equal in Mohakhali residential area. Recreation is found to be the primary reason behind RTG whereas Organic food production for the family in this city life become the secondary pleasure in roof gardening.

\subsection{Plants and Plantation technique}

$50 \%$ of the respondents produce vegetables, fruits, and flower altogether in their gardens. Whereas rests of the respondents produce either of the plant type or any combination of them. In most cases, people have used two types of technique-Planter type (large drum and pot) or extensive type (permanent masonry planter box). $78 \%$ of respondents use planter technique for rooftop gardening. $17 \%$ of the respondents use both planter and extensive rooftop gardening technique whereas only one case found who use planter and intensive gardening method for rooftop gardening. People use the large drum, plastic containers and soil pots as planters for growing different types of. Among the thirty respondents, two respondents mentioned using only large drum planter as they only grow fruits. For creating extensive rooftop garden people of the study area construct a base with brick and concrete covered with a plastic sheet. Above it, they place soil with a depth varying from 1 foot to 3 feet. The soil layer is walled with brick and concrete. This is the general method they use for the extensive or intensive type of gardening.
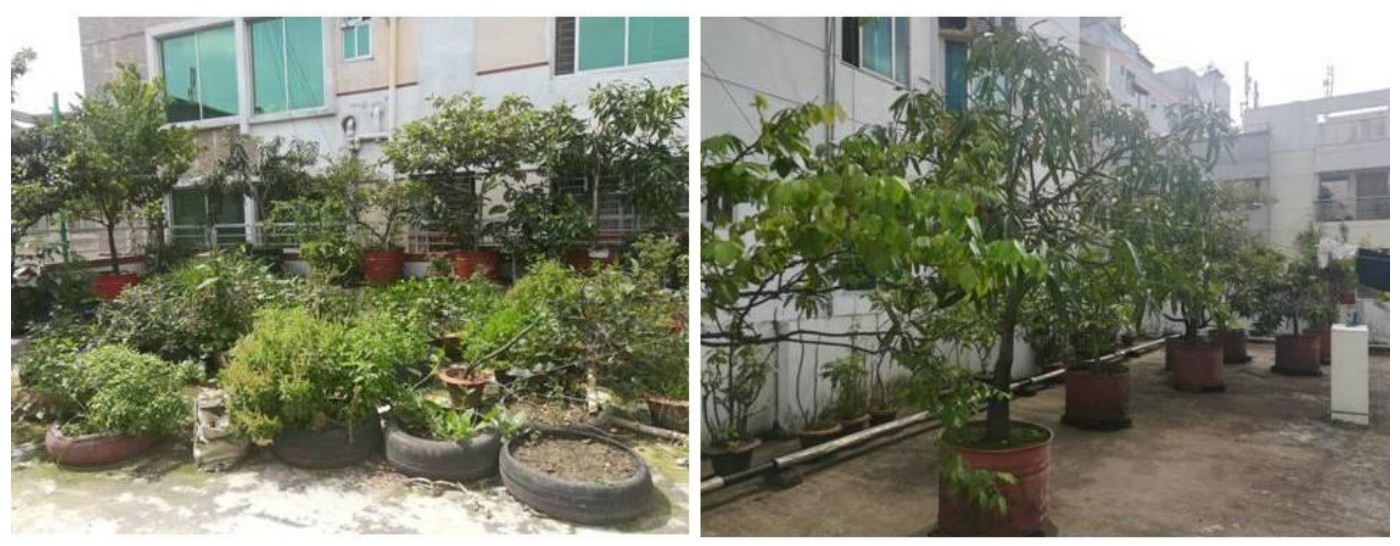

Figure 3 Roof Top Gardening Scenario in Research Area

Source Field survey, 2019

\subsection{Collection of Gardening equipment}

People of the study area collects their gardening equipment i.e. plats, seeds, fertilizer, soil, pesticide from nursery but they also followed other methods too i.e. random collection of seedlings (village house, , etc.). Two cases were found where the garden owner started gardening with the own seedbed and plant collection. They collect gardening equipment from random spots. The nearest nursery of the area is BRAC nursery which is $<500 \mathrm{~m}$ from 
the Gulshan Niketan area and 500m-1 km from Mohakhali area. Four cases were found who collect their equipment from the nursery that is located $>1 \mathrm{~km}$.

\subsection{Costing of RTG}

$40 \%$ of the respondents mentioned that they spend $<5000$ take for starting the rooftop garden. $28 \%$ spend 5000 tk to 20,000 takes as an initial cost of rooftop gardening. Rest $32 \%$ spent more than 20000 takas.

\subsection{Challenges of RTG}

The survey finds that $99 \%$ of the people who has roof garden do not face any structural error for roof gardening in their building. Only $1 \%$ respondent showed concern about the dampness. $45 \%$ of the respondent didn't find any difficulties for roof gardening. $22 \%$ of respondents think lifting goods to the rooftop and maintenance are challenges for a rooftop garden. The other $23 \%$ responds that watering, bugs, insects, and problems are a hindrance for roof gardening.

\subsection{Impact of RTG on urban heat reduction}

$32 \%$ of respondent suggested that they didn't find any benefits in heat reduction. If we analyze the square fit of the plantation, we see that the percentage of green with the total floor area is below $30 \%$. It indicates that if a good amount of floor area is not covered then we are not going to get the full benefit of roof plantation. The respondent also suggested that if they move from the current location, they will continue gardening in their new home too. Only $18 \%$ wasn't sure or reluctant to continue gardening. Those who are tenant complained that sometimes landlord doesn't allow them to use the roof for gardening. But if they are given opportunity, they are very enthusiastic about the rooftop garden.

\section{Recommendations}

The respondents of the survey area recommend many suggestions to inspire roof gardening. Creating social awareness is the most recommended, government incentive - in forms of tax reduction, supplying plants and seeds are the second highest suggestion. Few respondents suggested that training and workshop from the government can be arranged to encourage roof gardening. One respondent suggested that government certified paid personnel from City Corporation can visit and help in the development and maintenance of RTG. Some respondents emphasized ensuring the access of the tenants for the purpose of gardening. This recommendation section of this research has been developed based on recommendations suggested by users and the best practices from worldwide.

\subsection{Ensuring the place of RTG in Bangladesh National Building Code}

The best practices from the world show that different countries have made green roof mandatory by adding policy in their building code (Inhabitect LLC (2014); Hui, 2014, Mastura, 2017). The current BNBC mentions about mandatory green around the building at the ground but does not mention anything regarding green on the rooftop (BNBC, 2012). A few design guidelines can be added to our BNBC code so that any structural hassles can be maintained easily. The "Imarat Nirman Bidhimaa-2008" already have a rule which excludes the water fountain, pergola roof, green/open to sky terrace and veranda from FAR included 
area to encourage people to design a building with more openness. The inclusion of green roof can increase the percentage of the extensive plantation. Design of the green roof can exempt construction area from the FAR included area. This research recommends reviewing current BNBC and adds a new policy on the green roof so that the builders, Architects, and engineers incorporate this policy into their design.

\subsection{Ensuring access to the roof}

Majority of the people living in the study area are either tenant or own one or multiple flats. People who live as a tenant in multi-storied buildings most often lack access to use the roof. This research has found some cases in the study area where the roof has been used for gardening by multiple flat owners or tenants who have access to the roof. This is a good example of developing rooftop gardens in a cooperative way. An initiative from Government is needed to ensure the free access of the tenants to use the roof for storing, drying clothes or gardening purpose. Such example has already been set by the Government o Taiwan (Hui, 2014). Government associations or NGOs can encourage the landlord, frat owner and tenants to develop rooftop garden in a cooperative manner.

\subsection{Property tax reduction}

Property tax reduction is currently a popular initiative taken in different states including New Yorkton inspire green in the building (Inhabitect LLC, 2014). Such tax incentive programs can be taken by the Bangladesh government which will surely encourage residents to develop gardens at roofs.

\subsection{Encouragement from Government and NGO's}

Survey findings indicate that regardless of urban facility and amenities dwellers of the overall city are very enthusiastic and carries a positive thought on roof gardening. The cost and hurdle ship don't discourage them rather arranging training and awareness program from the government can increase the percentage of proactive people who loves gardening. Making people aware of the benefits of rooftop gardening through mass media can be another way of informing people about RTG. Government or NGOs can launch programs aiming at encouraging people for RTG. They can provide free soil, seeds, fertilizers, plants to people as a part of the encouragement for developing rooftop gardens. They also can initiate small loans programs to encourage RTG.

\section{Conclusions}

Although Gulshan Niketon Housing area and Mohakhali Shantiniketon residential area are located in the same ward, they differ in both planning and spatial characteristics. Nevertheless, the positive feedback and enthusiasm are almost the same from both the areas. People living in planned Gulshan Niketon housing area and organically developed Mohakhali residential area try to establish a rooftop garden according to their ability. The research findings acknowledge that there is a huge scope of making people encouraged at vast scale on developing rooftop gardens at residential areas. Many people have hidden wish to have a garden at home but they lack inspirations, proper guidance, and scope to use the hard surface of the building. It suggests that using the current crush for rooftop gardening to reduce the hardscape of Dhaka city will not be challenging form user point of view. Most 
of the users are indifferent of the challenges of developing a rooftop garden as they hold a very positive attitude towards RTG. Furthermore, maximum users believe that RTG helps to cool down the microclimate of the roof. This research has found out that large scale RTG contributes significantly to cool down the temperature of the top floor of the building rather than small scale RTG. It is the responsibility of professional and policymaker to start a positive ripple of roof gardening in an urban scale. RTG at urban scale will not only benefit to reduce UHI effect but also bless the city with aesthetical and psychological benefits.

\section{References}

Amin, Mehedi Al (2019) "Dhaka remains the world's most densely populated city", Dhaka Tribune

Carroll, Maureen (2003) "Earthly paradise: Ancient Gardens in History and Archaeology", Los Angeles, The J Paul Getty Museum

Cartwright, Mark (2018) “Hanging Gardens of Babylon”, Ancient History Encyclopedia

Chicago Dept. of Environment (n.d) "Chicago's Green Roofs: A Guide to Rooftop Gardening", Chichago, ComEd

Daniel, Gomez; Montero, Javier (2011) "Determining the accuracy in image supervised classification problems", EUSFLAT-LFA 2011, Aix-les-Bains, France (July)

Dhaka North City Corporation (2016) "Geographical Location \& Area of DNCC" http://old.dncc.gov.bd/geographical-location-area-of-dncc/

Field Survey (2019) "Field Survey in Ward 20 for questionnaire survey and collecting photographs conducted by authors"

Goodchild, Michael (2009) "Geographic Information Systems and Science: Today and Tomorrow", Procedia Earth and Planetary Science, 1,

Hossain, Md Aslam; Shams, Shahriar; Amin, Mahmud; Reza, Md Sumon; Chowdhury, Tanvir Uddin (2019), "Perception and Barriers to Implementation of Intensive and Extensive Green Roofs in Dhaka, Bangladesh", MDPI.

Hui, Sam C M (2011), "Green roof urban framing for high-density urban cities", the Hainan China World Green Roof Conference, Hainan (Haikuo, Boao, and Sanya), China.

Inhabitant LLC (2014) "Green roof policies and guidelines, North American green roof policy guide", Green Roof for Healthy Cities

Islam, Khandaker, M, Shariful (2004) "Rooftop Gardening as a Strategy of Urban Agriculture for Food Security: The Case of Dhaka City, Bangladesh", International Conference on Urban Horticulture

Jafari, Neda; Utaberta, Nangkula; Yunos, Mohd; Ismail, Nor (2015) "Benefits of Roof Garden in Order to Usage of Urban Agriculture at Roof Garden in High-Rise Building in Malaysia", AENSI, November. 
Lambert, Tim (2019) "A Brief History of Gardening". http://www.localhistories.org/gardening.html

Maheng, Dikman; Ducton Ishara; Lauwaet Dirk; Zevenbergen, Chris; Pathirana, Assela (2019), "The Sensitivity of Urban Heat Island to Urban Greenspace-A Model-Based Study of City of Colombo, Sri Lanka", MDPI.

Managbanang, Emmanuel Linguaje (2013) "Ancient Gardens" https://www.scribd.com/document/167833589/Ancient-Gardens

Mediabangladesh.Net (N.D) "Dhaka city Map-South and north City Corporations" https://www.mediabangladesh.net/dhaka-city-map-south-and-north-city-corporation/

Parvin, nigar sultana; Abudu, Dan (2017), "Estimating Urban Heat Island Intensity using Remote Sensing Technique", International Journal of Scientific \& Engineering Research, Vol_8_april.

Patnaik, Binaya (2018), "impact of green roof in urban living", International Journal of current engineering and technology, Vol_8_December.

Poddar, Sinchita; Park, Dong Yoon; Chang, Seongju (2017). Simulation Based Analysis on the Energy Conservation Effect of Green Wall Installation for Different Building Types in a Campus. In 8th International Conference on Sustainability in Energy and Buildings, SEB-16,. Turin: Elsevire.

Rahman, Rafida Syumi; Hamidah, Ahmad; Mohammad, Sapura; Rosley, Solehin, Muhamad, Fitry (2017) "Perception of Green Roof as a Tool for Urban Regeneration in a Commercial Environment: Secret Garden Malaysia", Procedia - Social and Behavioural Sciences, Elsevier, 170 (2015)

RAJUK (2004) "Detailed Area Plan DAP Final Plan of Dhaka Metropolitan Development Area" RAJUK

RAJUK (2015) “Draft Dhaka Structure Plan 2016-2035”, RAJUK

Rowe D. Bradley (2011) "Green roofs as a means of pollution abatement" Environmental Pollution, Elsevier 159 (2011)

Roy, s; Datta, S; Haque, M.M (2016) “Urban forestry and urban greening for the sustainable urban development-A case of Dhaka north city corporation area (Zone-1)", J. Bangladesh Agril. Univ. V 14 No2

Safayet, Mastura; Arefin Md. Faqrul; Hasan, Md. Musleh Uddin (2017) "Present practice and future prospect of rooftop farming in Dhaka city: A step towards urban sustainability", Journal of Urban Management, Vol 6 (2017)

Shamim. H (2013) "A brief history of roof garden”, Heather Shamim Photography

Shuvo, Faysal Kabir; Hakim, Sheikh Serajul (2013), "A Proposed Framework for Regenerating Urban Green in Dhaka City," Bangladesh Institute of planners, vol_6_december.

Spacey, J (2016) "Green roof vs rooftop gardening", Simplicable

Vazhacharickal, Prem Jose (2014), "balcony and terrace gardens in urban greening and local food production: scenarios from Mumbai metropolitan region (MMR), India", International Journal of Food, Agriculture and Veterinary Sciences, Vol 2, August. 